\title{
AGRONOMIC PERFORMANCE OF COWPEA CULTIVARS DEPENDING ON SOWING SEASONS IN THE CERRADO BIOME ${ }^{1}$
}

\author{
FERNANDO DA SILVA ALMEIDA² ${ }^{2 *}$ FÁBIO LUIZ CHECCHIO MINGOTTE ${ }^{3}$ LEANDRO BORGES LEMOS ${ }^{3}$, \\ MÁRCIO JOSÉ DE SANTANA ${ }^{2}$
}

\begin{abstract}
The objective of this work was to assess the agronomic performance of cowpea cultivars depending on sowing seasons in the Cerrado biome. Thus, an experiment was conducted in Uberaba, State of Minas Gerais, Brazil, in a complete randomized block design, in a 6x3 factorial arrangement, using six cowpea cultivars (BRS-Itaim, BRS-Guariba, BRS-Potengi, BRS-Cauamé, BRS-Novaera and BRS-Tumucumaque) and three sowing seasons (Dec 14, 2012; Jan 14, 2013; and Feb 14, 2013), with four replications. The interaction between the cultivars and sowing seasons was assessed regarding the number of days for full flowering, number of days for pod maturation, number of trifoliate leaves, height of the first pod-bearing node, pod length, number of pods per plant, final plant population, 100-grain weight and grain yield. The cowpea cultivars sown in December produced the lowest numbers of pods per plant and grains per pod, resulting in the lowest grain yields. The cultivar BRS-Tumucumaque had the highest grain yield in the January sowing. The highest grain yields were found in the February sowing, especially when the cultivars BRS-Itaim $\left(3,439 \mathrm{~kg} \mathrm{ha}^{-1}\right)$, BRS-Novaera $\left(3,435 \mathrm{~kg} \mathrm{ha}^{-1}\right)$, BRS-Guariba $\left(3,168 \mathrm{~kg} \mathrm{ha}^{-1}\right)$ and BRS-Potengi $\left(3,107 \mathrm{~kg} \mathrm{ha}^{-1}\right)$ was used.
\end{abstract}

Keywords: Vigna unguiculata. Genotypes. Sowing seasons. Production components. Grain yield.

\section{DESEMPENHO AGRONÔMICO DE CULTIVARES DE FEIJÃO-CAUPI EM FUNÇ̃̃O DAS ÉPOCAS DE SEMEADURA NO CERRADO DE UBERABA-MG}

RESUMO - O objetivo do trabalho foi avaliar o desempenho agronômico de cultivares de feijão-caupi em função de épocas de semeadura no cerrado de Uberaba, MG. O experimento foi conduzido em Uberaba-MG, no delineamento de blocos casualizados, em arranjo fatorial 6 x 3, correspondendo a seis cultivares de feijão-caupi (BRS Itaim, BRS Guariba, BRS Potengi, BRS Cauamé, BRS Novaera e BRS Tumucumaque) e três épocas de semeadura (14/dez/2012 - E1, 14/jan/2013 - E2 e 14/fev/2013 - E3), com quatro repetições. Verificou-se interação cultivares x épocas de semeadura para o número de dias para o florescimento pleno, dias para a maturação das vagens, número de trifólios, altura de inserção da primeira vagem, comprimento de vagens, número de vagem por planta, população final de plantas, massa de 100 grãos e produtividade de grãos. Quando semeadas em dezembro, as cultivares de feijão- caupi produziram menor número de vagens por planta e de grãos por vagem, resultando em inferior produtividade de grãos. A cultivar BRS Tumucumaque apresentou maior produtividade de grãos quando semeada em janeiro. Produtividades de grãos superiores são obtidas na semeadura de fevereiro, sobressaindo-se as cultivares BRS Itaim, BRS Novaera, BRS Guariba e BRS Potengi, com 3.439, 3.435, 3.168 e $3.107 \mathrm{~kg} \mathrm{ha}^{-1}$, respectivamente.

Palavras-chave: Vigna unguiculata. Genótipos. Períodos de cultivo. Componentes de produção. Produtividade de grãos.

\footnotetext{
*Corresponding author

${ }^{1}$ Received for publication in 06/23/2015; accepted in 07/29/2016.

Paper extracted from the Master Dissertation of the first author.

${ }^{2}$ Instituto Federal do Triângulo Mineiro, Uberaba, MG, Brazil; fernandosilva@iftm.edu.br, marciosantana@iftm.edu.br.

${ }^{3}$ Department of Plant Production, Universidade Estadual Paulista "Júlio de Mesquita Filho", Jaboticabal, SP, Brazil; flcmingotte@gmail.com, leandrobl@fcav.unesp.br.
} 


\section{INTRODUCTION}

Cowpea (Vigna unguiculata (L.) Walp, Fabaceae) is cultivated in semiarid regions of Africa, United States of America and Brazil (MORTIMORE et al., 1997; ROCHA et al., 2009; EZEAKU; MBAH; BAIYERI, 2015). It is one of the main components of the diet of Brazilians, especially in the North and Northeast regions, in which the cowpea production is concentrated. However, the cowpea crop average yield in Brazil ranges between 400 and $500 \mathrm{~kg} \mathrm{ha}^{-1}$, far below its productive potential, estimated in 5,000 to $6,000 \mathrm{~kg} \mathrm{ha}^{-1}$ (HALL et al., 2003; ALVES et al., 2009).

Cowpea has emerged as a crop of significant interest due to its adaptation to extreme environmental conditions, such as high temperatures and water deficit (OCHIENG; KIRIMI; MATHENGE, 2016). Moreover, cowpea presents very competitive production costs, compared with other agricultural species, contributing to the increasing interest for income diversification in rural properties. Thus, the cowpea crop is expanding to the Brazilian Midwest and Southeast regions as an option for winter crop, after the soybean, corn and rice summer crops, reaching yields above $1,000 \mathrm{~kg} \mathrm{ha}^{-1}$. This expansion was due to the development of new cultivars with compact and erect characteristics, favoring mechanization (FREIRE FILHO et al., 2011), and responsive to soil fertility, and due to the benefits of rotation with other agricultural species, ensuring a more sustainable crop system (HALL et al., 2003).

Teixeira et al. (2010) studied cowpea crop in a dry season in Catalão, Goias, Brazil, and observed adaptation of the cultivars BRS-Guariba (grain yield of 2,211 ha ${ }^{-1}$ ) and /87BR17-Gurguéia $\left(2,196 \mathrm{~kg} \mathrm{ha}^{-1}\right)$ to the local climatic conditions. Matoso et al. (2013) found that the grain yield of the cultivar BRS-Novaera ranged from $779 \mathrm{~kg} \mathrm{ha}^{-1}$ (2010) to $1756 \mathrm{~kg} \mathrm{ha}^{-1}$ (2009), during the winter crop, in Dourados, Mato Grosso do Sul. These same researchers found grain yields of $1,180 \mathrm{~kg} \mathrm{ha}^{-1}$ (cultivar BRS-Guariba), 1,164 kg ha-1 (cultivar $B R S$-Novaera) and $1,150 \mathrm{~kg} \mathrm{ha}{ }^{-1}$ (cultivar $B R S$-Xiquexique) in Botucatu, São Paulo.

Assessments on agronomic performance of cultivars and indications of the most appropriate sowing season to different soil and climatic conditions are essential to ensure the regional recommendations for the crop, due to the genotype $\mathrm{x}$ environment interactions (BARROS et al., 2013; EZEAKU; MBAH; BAIYERI, 2015). Therefore, air temperature, precipitation, and especially the rainfall distribution, are essential factors to the determination of the cowpea sowing season (CARDOSO; MELO; LIMA, 2005; SANTOS et al., 2009; FREITAS et al., 2013; MATOSO, 2014).

In this context, the objective of this work was to assess the agronomic performance of cowpea cultivars depending on sowing seasons in the Cerrado biome, in Uberaba, State of Minas Gerais, Brazil.

\section{MATERIAL AND METHODS}

The experiment was implemented and conducted in the experimental area of the Instituto Federal do Triângulo Mineiro, in Uberaba, State of Minas Gerais (19³9'19"S, 47 $57^{\circ} 27^{\prime \prime} \mathrm{W}$, and altitude of $795 \mathrm{~m}$ ). The climate of the region is Cwa, according to the Köppen classification, presenting annual average precipitation of 1,600 $\mathrm{mm}$ and annual average temperature of $22.6^{\circ} \mathrm{C}$. The maximum and minimum air temperatures and precipitation were daily collected during the experiment (Figures 1A, $1 \mathrm{~B}$ and $1 \mathrm{C})$.

The soil of the experimental area was classified as Oxisol with sandy loam texture, and had the following chemical attributes in the topsoil $(0-0.2 \mathrm{~m}): \mathrm{pH}$ in $\mathrm{H}_{2} \mathrm{O}=6.3 ; \mathrm{P}=24.4 \mathrm{mg} \mathrm{dm}^{-3}$; $\mathrm{K}=89.4 \mathrm{mg} \mathrm{dm}{ }^{-3} ; \mathrm{Ca}=1.9 \mathrm{cmol}_{\mathrm{c}} \mathrm{dm}^{-3}$; $\mathrm{Mg}=0.7 \mathrm{cmol}_{\mathrm{c}} \mathrm{dm}^{-3} ; \mathrm{H}+\mathrm{Al}=1.9 \mathrm{cmol}_{\mathrm{c}} \mathrm{dm}^{-3} ;$ base saturation $=59.8 \%$; and organic matter $=1.0$ dag $\mathrm{kg}^{-1}$.

A complete randomized block design in a $6 \times 3$ factorial arrangement with four replications was used, with six cowpea cultivars (BRS-Itaim, BRS-Guariba, BRS-Potengi, BRS-Cauamé, BRS-Novaera and BRS-Tumucumaque), and three sowing seasons (December 14, 2012; January 14, 2013; and February 14, 2013). Each plot consisted of four 5-meter-long rows of plants, considering the two central rows as the area of evaluation, discarding $0.5 \mathrm{~m}$ from each end.

The soil was prepared in conventional system, with a plowing and two harrowings. The seeds of the cowpea cultivars were from the Embrapa Mid-North Breeding Program. Sowing was performed manually, distributing 12 seeds per meter, with $0.40 \mathrm{~m}$ between rows. After seedling emergence, the average stand was eight plants per meter, equivalently to 200,000 plants per hectare (CARDOSO; MELO; LIMA, 2005).

Sowing fertilization was performed with $20 \mathrm{~kg} \mathrm{ha}^{-1}$ of $\mathrm{P}_{2} \mathrm{O}_{5}$ (superphosphate) and $20 \mathrm{~kg} \mathrm{ha}^{-1}$ of $\mathrm{K}_{2} \mathrm{O}$ (potassium chloride) in the sowing furrows. Topdressing was performed 25 days after seedling emergence (DAE) with $20 \mathrm{~kg} \mathrm{ha}^{-1}$ of $\mathrm{N}$ (urea) (MELO; CARDOSO; SALVIANO, 2005).

Weed control was performed by hand-hoeing at 15 and $30 \mathrm{DAE}$ in the three sowing seasons.

The number of days between sowing and full flowering $(50 \%$ of the plants with the first flower opened) was evaluated during the experiment, as well as the pod maturation (number of days between sowing and almost all pods were dried). 
1A) Precipitation - Maximum temperature $\cdots$ - Minimum temperature

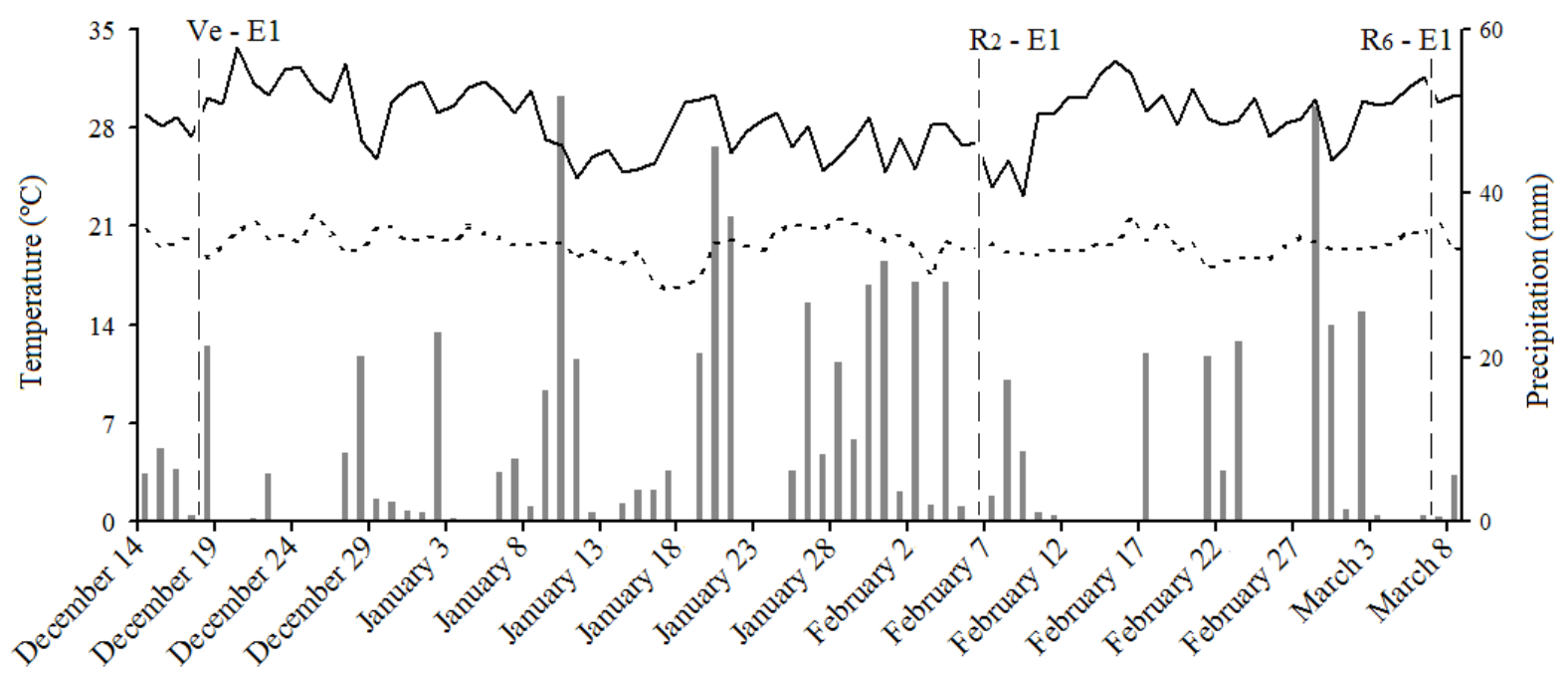

1B)

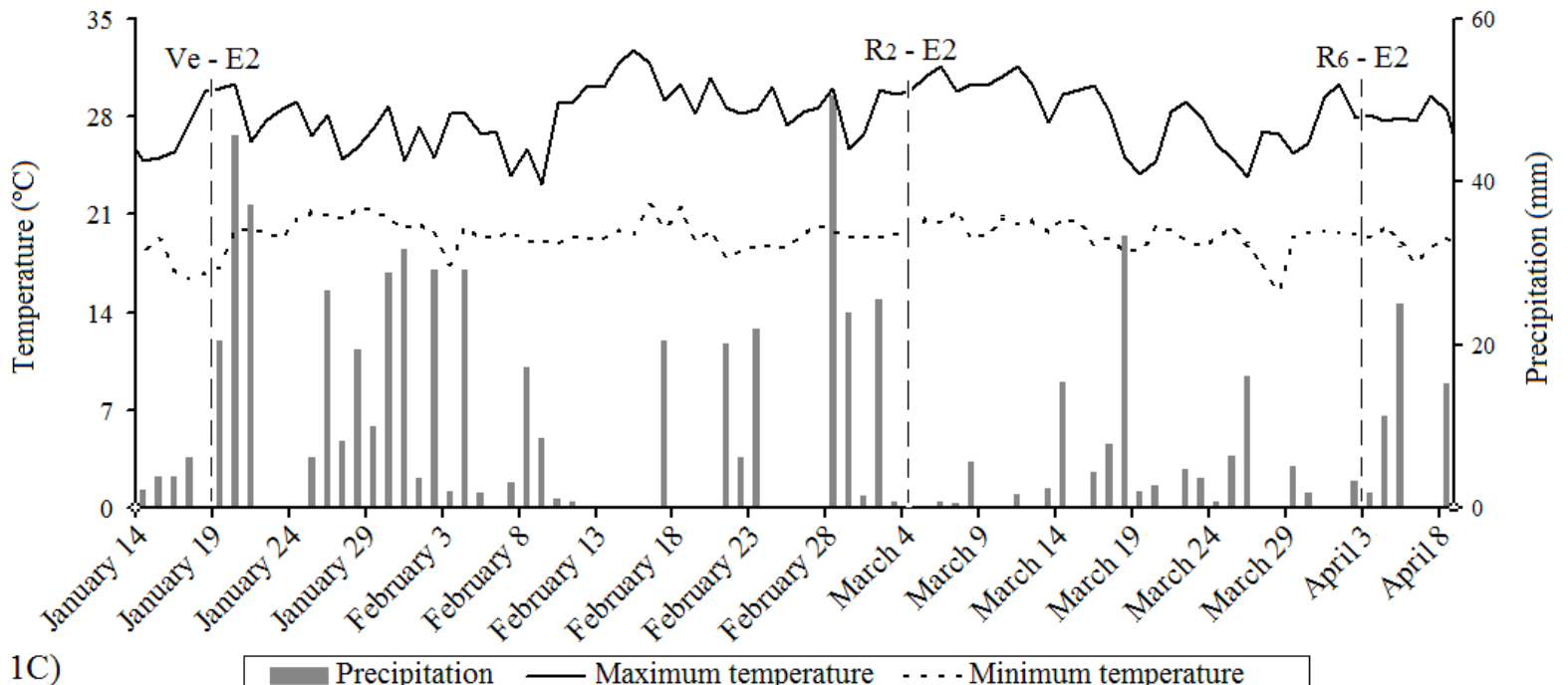

1C)

Precipitation — Maximum temperature -..- Minimum temperature

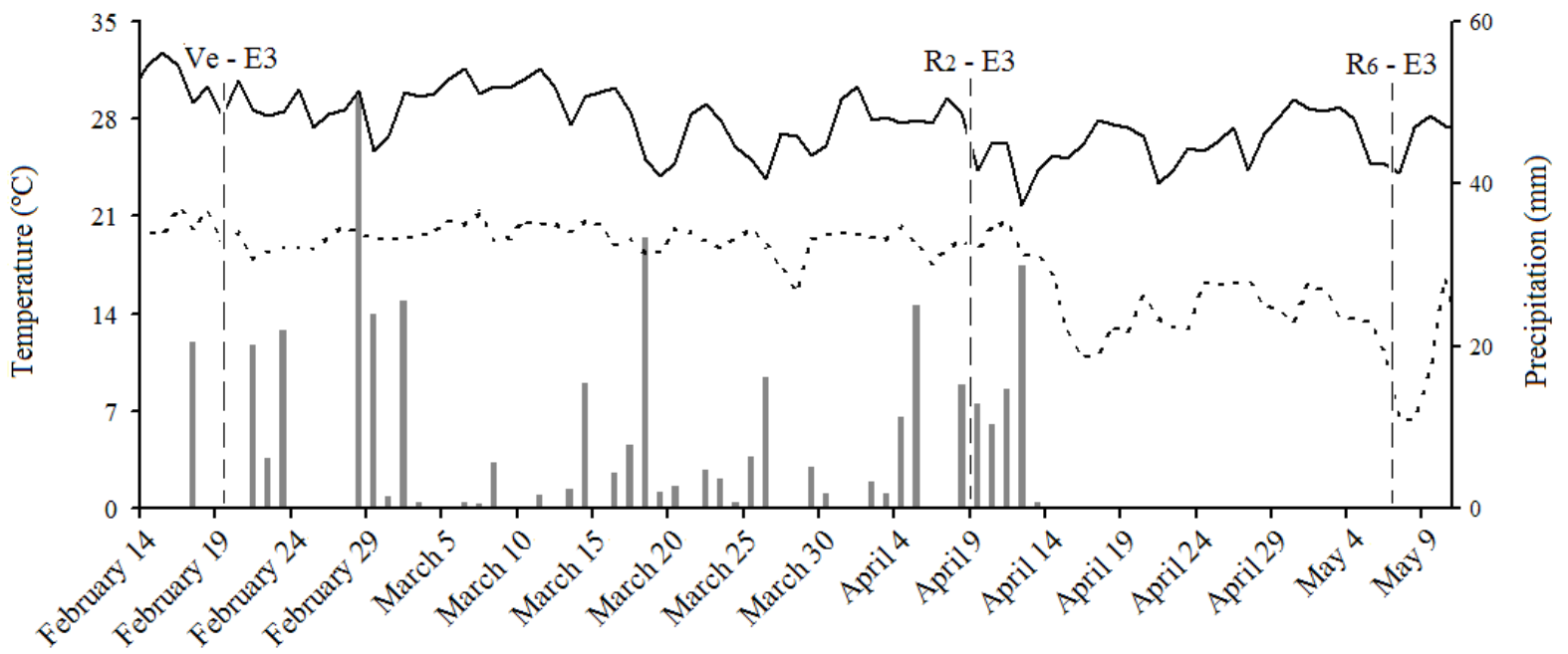

Figure 1. Average data of precipitation and maximum and minimum temperature of every five days, during the period from December 2012 to May 2013 in the experimental area, in Uberaba, Minas Gerais, Brazil. $\mathrm{V}_{\mathrm{E}}=$ emergence, $\mathrm{R}_{2}=$ full flowering, $\mathrm{R}_{6}=$ physiological maturation. $1 \mathrm{~A}=$ Sowing at December 14,$2012 ; 1 \mathrm{~B}=$ Sowing at January 14,2013 ; $1 \mathrm{C}=$ Sowing at February 14, 2013. 
The number of trifoliate leaves per plant at full flowering was found by counting them in five plants of each plot. These plants were collected and dried in a forced-air circulation oven at $60-70^{\circ} \mathrm{C}$ for 72 hours, to assess their shoot dry weight.

The final plant population was found after the physiological maturation of each cultivar. Ten plants of each plot were collected to determine the height $(\mathrm{mm})$ of the first pod-bearing node (distance from plant cervix to the first pod-bearing node) and length $(\mathrm{mm})$ of the pods of the lower third of each plant.

These 10 plants were also used to determine the number of pods per plant and number of grains per pod, i.e., the total number of grains divided by the total number of pods. The 100-grain weight was found by counting and weighing four samples of 100 grains per experimental plot, after their water content were corrected to $13 \%$ (wet basis).

Harvest was performed at physiological maturation of the plants, manually collecting the pods in the area of evaluation of each plot. The harvested pods were sun dried for three days and then threshed by hand. The resulting grain samples were weighed to determine the grain yield $\left(\mathrm{kg} \mathrm{ha}^{-1}\right)$ at $13 \%$ (wet basis) of water content.

The data were subjected to analysis of variance using the $\mathrm{F}$ test, and means were compared by the Tukey test at $5 \%$ probability. The unfolding of the respective degrees of freedom was carried out when the interaction between cultivars and sowing seasons was significant.

\section{RESULTS AND DISCUSSION}

The number of days for the pod full flowering and maturation, number of trifoliate leaves per plant, pod length, number of pods per plant, height of the first pod-bearing node, final plant population, 100 -grain weight and grain yield were affected by the interaction of cowpea cultivars and sowing seasons (Table 1).

Table 1. Analysis of variance of the full flowering, pod maturation, number of trifoliate leaves per plant, pod length, number of pods per plant, height of the first pod-bearing node, final plant population, 100-grain weight and grain yield of six cowpea cultivars depending on different sowing seasons, in the Cerrado biome. Uberaba, Minas Gerais, Brazil, 2012/13.

\begin{tabular}{|c|c|c|c|}
\hline Source of variation & $\begin{array}{c}\text { Full } \\
\text { flowering } \\
\text { (number of days) }\end{array}$ & $\begin{array}{c}\text { Pod } \\
\text { maturation } \\
\text { (number of days) }\end{array}$ & $\begin{array}{c}\text { Trifoliate leaves } \\
\text { per plant } \\
\text { (number) }\end{array}$ \\
\hline Cultivars (C) & $152.35 * *$ & $276.23 * *$ & $67.46^{* *}$ \\
\hline Sowing seasons (S) & $260.22 * *$ & $340.16^{* *}$ & $253.76^{* *}$ \\
\hline $\mathrm{C} \times \mathrm{S}$ interaction & $64.22 * *$ & $64.70 * *$ & $26.817 * *$ \\
\hline CV (\%) & 3.06 & 2.09 & 15.7 \\
\hline General average & 54 & 84 & 17 \\
\hline Source of variation & $\begin{array}{c}\text { Pod } \\
\text { length } \\
(\mathrm{cm})\end{array}$ & $\begin{array}{c}\text { Pods per } \\
\text { plant } \\
\text { (number) }\end{array}$ & $\begin{array}{l}\text { Height of the first } \\
\text { pod-bearing node } \\
(\mathrm{cm})\end{array}$ \\
\hline Cultivars (C) & $16.23 * *$ & $8.24 * *$ & $45.46^{* *}$ \\
\hline Sowing seasons (S) & $4.21 * *$ & $321.85 * *$ & $2,077.97 * *$ \\
\hline $\mathrm{C} \times \mathrm{S}$ interaction & $1.68 * *$ & $6.56 * *$ & $86.0 * *$ \\
\hline CV (\%) & 3.7 & 10.45 & 5.39 \\
\hline General average & 17 & 7 & 59.8 \\
\hline Source of variation & $\begin{array}{l}\text { Final plant population } \\
\quad\left(\text { plants }^{-1} \mathrm{a}^{-1}\right)\end{array}$ & $\begin{array}{l}\text { 100-grain } \\
\text { weight } \\
(\mathrm{g}) \\
\end{array}$ & $\begin{array}{c}\text { Grain } \\
\text { yield } \\
\left(\mathrm{kg} \mathrm{ha}^{-1}\right)\end{array}$ \\
\hline Cultivars $(\mathrm{C})$ & $1.88 * *$ & $48.03 * *$ & $725,361.12^{* *}$ \\
\hline Sowing seasons (S) & $2.85 * *$ & $12.08 * *$ & $24,141,525.72 * *$ \\
\hline $\mathrm{C} \times \mathrm{S}$ interaction & $2.76^{* *}$ & $11.32 * *$ & $719,021.88 * *$ \\
\hline CV $(\%)$ & 10.89 & 6.3 & 7.74 \\
\hline General average & 184,305 & 19.3 & 2,105 \\
\hline
\end{tabular}

** significant at $1 \%$ probability by the $\mathrm{F}$ test.

The flowering of the cultivar BRS-Novaera was longer in the sowing seasons of December 14, 2012 (S1) and January 14, 2013 (S2) (Table 2). However, this cultivar reached its full flowering with the lowest number of days in the sowing season of February 14, 2013 (S3), which was similar to the cultivar BRS-Potengi. The cultivar BRS-Novaera reached pod maturation at 95 days after sowing
(DAS), the longest time compared with the other cultivars in $\mathrm{S} 1$, followed by the BRS-Itaim, with 90 DAS (Table 2). These cultivars had similar performances in S2 and S3, with no significant differences between them. The cowpea cultivars in S3, in general, needed a higher number of days to reach pod maturation, compared with the other sowing seasons, except the BRS-Novaera. The 
milder night temperatures during the experiment (Figures 1A, 1B and 1C) contributed to this result. According to Campos, Silva and Silva (2010), temperatures ranging from 20 to $30^{\circ} \mathrm{C}$ is considered as optimal for the cowpea development, while temperatures below $19^{\circ} \mathrm{C}$ increases the vegetative period and delays the flowering, increasing the crop cycle.

Table 2. Unfolding of interaction between cultivars and sowing seasons for the full flowering and pod maturation of six cowpea cultivars depending on different sowing seasons, in the Cerrado biome. Uberaba, Minas Gerais, Brazil, 2012/13.

\begin{tabular}{|c|c|c|c|c|c|c|}
\hline \multirow{3}{*}{ Cultivars } & \multicolumn{4}{|c|}{$\begin{array}{l}\text { Full flowering } \\
\text { (number of days) }\end{array}$} & \multicolumn{2}{|c|}{$\begin{array}{l}\text { Pod maturation } \\
\text { (number of days) }\end{array}$} \\
\hline & \multicolumn{6}{|c|}{ Sowing seasons } \\
\hline & $\mathrm{S} 1$ & $\mathrm{~S} 2$ & S3 & $\mathrm{S} 1$ & $\mathrm{~S} 2$ & S3 \\
\hline BRS-Itaim & $58 \mathrm{aA}$ & $55 \mathrm{bB}$ & $58 \mathrm{abA}$ & $90 \mathrm{bAB}$ & $88 \mathrm{aB}$ & $91 \mathrm{aA}$ \\
\hline BRS-Guariba & $48 \mathrm{bB}$ & $49 \mathrm{cB}$ & $58 \mathrm{abA}$ & $76 \mathrm{cC}$ & $82 \mathrm{cB}$ & $87 \mathrm{bA}$ \\
\hline BRS-Tumucumaque & $45 \mathrm{bC}$ & $49 \mathrm{cB}$ & $58 \mathrm{abA}$ & $74 \mathrm{cC}$ & $78 \mathrm{~dB}$ & $87 \mathrm{bA}$ \\
\hline BRS-Novaera & $59 \mathrm{aB}$ & $62 \mathrm{aA}$ & $55 \mathrm{bcC}$ & $95 \mathrm{aA}$ & $87 \mathrm{abC}$ & $91 \mathrm{aB}$ \\
\hline BRS-Potengi & $47 \mathrm{bB}$ & $49 \mathrm{cB}$ & $54 \mathrm{cA}$ & $76 \mathrm{cC}$ & $82 \mathrm{cB}$ & $87 \mathrm{bA}$ \\
\hline BRS-Cauamé & $48 \mathrm{bC}$ & $55 \mathrm{bB}$ & $61 \mathrm{aA}$ & $74 \mathrm{cC}$ & $84 \mathrm{bcB}$ & $87 \mathrm{bA}$ \\
\hline
\end{tabular}

Means followed by the same lowercase letter in the column and uppercase letter on the row, do not differ by the Tukey test at 5\% probability. S1 = December 14, 2012; S2 = January 14, 2013; S3 = February 14, 2013.

Regarding the effect of the sowing seasons, most cowpea cultivars had higher number of trifoliate leaves per plant in S1, compared with S2 and S3 (Table 3). This result can be due to the higher precipitation and favorable temperatures in $\mathrm{S} 1$ (Figures 1A, 1B and 1C) to the cowpea vegetative development. The cultivar BRS-Novaera stood out regarding the number of trifoliate leaves per plant in the three sowing seasons, however, it did not differ from the other cultivars in $\mathrm{S} 1$, from BRS-Itaim in $\mathrm{S} 2$ and $\mathrm{S} 3$, and from BRS-Cauamé in S3.

Table 3. Unfolding of interaction between cultivars and sowing seasons for the number of trifoliate leaves per plant, pod length and number of pods per plant of six cowpea cultivars depending on different sowing seasons, in the Cerrado biome. Uberaba, Minas Gerais, Brazil, 2012/13.

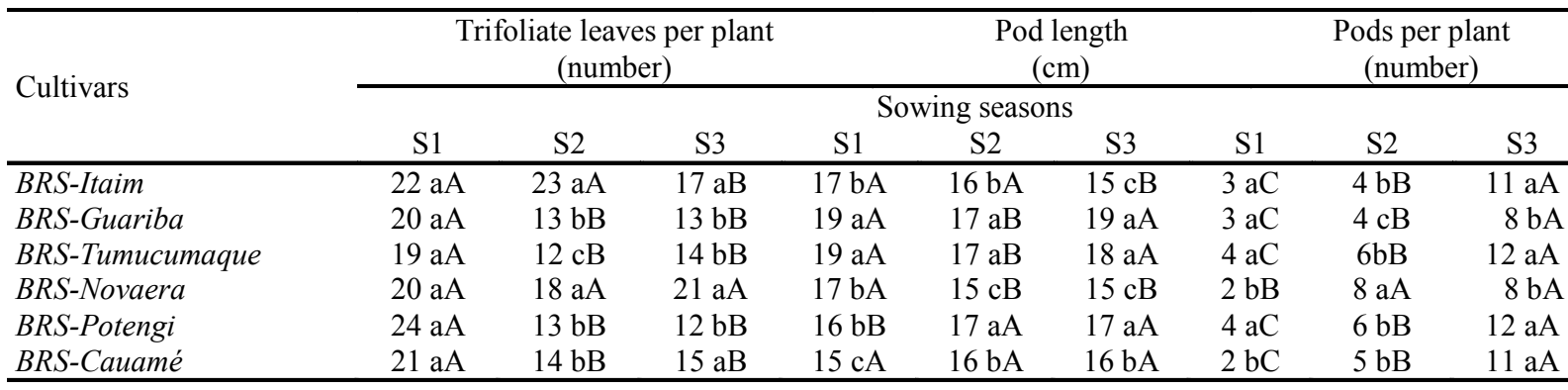

Means followed by the same lowercase letter in the column and uppercase letter on the row, do not differ by the Tukey test at 5\% probability. S1 = December 14, 2012; S2 = January 14, 2013; S3 = February 14, 2013.

The unfolding analysis of the interaction between cultivars and sowing seasons showed greater pod lengths for the cultivars BRS-Guariba and BRS-Tumucumaque in the three sowing seasons, the BRS-Potengi also stood up in the S2 and S3 (Table 3). The results found, in general, were similar to those found by Silva and Neves (2011), who evaluated 20 cowpea cultivars and reported average pod length of $19.7 \mathrm{~cm}$. Silva et al. (2013) evaluated 8 cowpea cultivars and found average pod length of $18.5 \mathrm{~cm}$, (20.9 cm for BRS-Tuтucumaque, $20.2 \mathrm{~cm}$ for BRS-Guariba, $18.3 \mathrm{~cm}$ for BRS-Potengi, $17.7 \mathrm{~cm}$ for BRS-Itaim and $16.4 \mathrm{~cm}$ for BRS-Cauamé). The pod length is related to grain yield. An ideal pod length is above $20 \mathrm{~cm}$, however, depending on the production system, for dried or green grains, small pods with large grain sizes can be the most desirable (SILVA; NEVES, 2011).
The cowpea cultivars in S3 had higher number of pods per plant (Table 3). Oliveira et al. (2013) found a high and positive correlation $(r=0.98)$ between the number of pods per plant and grain yield in cowpea. The cultivars BRS-Tumucumaque and BRS-Potengi had higher number of pods per plant compared with the other cultivars in $\mathrm{S} 1$ and $\mathrm{S} 3$. The cultivar BRS-Novaera had higher number of pods per plant in S2 compared with the other cultivars. The values found were close to the average (10 pods per plant) reported by Santos et al. (2009) in the Cariri Paraibano region, Piaui, Brazil.

The height of the first pod-bearing node was similar for the six cultivars in S1 (Table 4). The S2 and S3, in general, provided higher heights of the first pod-bearing node for all cultivars, except for the BRS-Novaera and BRS-Cauamé, which stood out alone in S2 (Table 4). Silva (2011) assessed the 
agronomic performance of cowpea in Vitória da Conquista, Bahia, Brazil, and found average values lower than those found in the present work (Table 4), regarding the height of the first pod-bearing node of the cultivars BRS-Itaim $(46 \mathrm{~cm}), B R S$-Potengi $(41 \mathrm{~cm})$, BRS-Guariba $(37 \mathrm{~cm})$ and BRS-Cauamé $(39 \mathrm{~cm})$. The height of the pod-bearing node is directly related to the cultivar growth habit. In general, this height is lower in plants with semi-prostrate and prostrate growth habit. According to Silva (2011), the height of the first pod-bearing node in cowpea is a genetic characteristic of each cultivar, which may vary according to the environmental and cultivation conditions.

Table 4. Unfolding of interaction between cultivars and sowing seasons for the height of the first pod-bearing node and final plant population of six cowpea cultivars depending on different sowing seasons, in the Cerrado biome. Uberaba, Minas Gerais, Brazil, 2012/13.

\begin{tabular}{|c|c|c|c|c|c|c|}
\hline \multirow{3}{*}{ Cultivars } & \multicolumn{3}{|c|}{$\begin{array}{c}\text { Height of the } \\
\text { first pod-bearing node }(\mathrm{cm})\end{array}$} & \multicolumn{3}{|c|}{$\begin{array}{c}\text { Final plant } \\
\text { population (plants ha }{ }^{-1} \text { ) } \\
\end{array}$} \\
\hline & \multicolumn{6}{|c|}{ Sowing seasons } \\
\hline & S1 & S2 & $\mathrm{S} 3$ & $\mathrm{~S} 1$ & S2 & S3 \\
\hline BRS-Itaim & $47.6 \mathrm{aB}$ & $71.6 \mathrm{aA}$ & $66.9 \mathrm{aA}$ & $91,250 \mathrm{bB}$ & $222,500 \mathrm{aA}$ & $200,000 \mathrm{aA}$ \\
\hline BRS-Guariba & $50.2 \mathrm{aB}$ & $62.0 \mathrm{bA}$ & $66.4 \mathrm{aA}$ & $175,000 \mathrm{aB}$ & $216,875 \mathrm{aA}$ & $180,625 \mathrm{aB}$ \\
\hline BRS-Титиситаqие & $50.1 \mathrm{aB}$ & $61.6 \mathrm{bA}$ & $63.7 \mathrm{aA}$ & $163,125 \mathrm{aB}$ & $213,750 \mathrm{aA}$ & $167,500 \mathrm{aB}$ \\
\hline BRS-Novaera & $50.1 \mathrm{aB}$ & $71.6 \mathrm{aA}$ & $52.8 \mathrm{bB}$ & $112,500 \mathrm{bC}$ & $216,875 \mathrm{aA}$ & $176,250 \mathrm{aB}$ \\
\hline BRS-Potengi & $48.0 \mathrm{aB}$ & $64.2 \mathrm{bA}$ & $61.9 \mathrm{aA}$ & $196,250 \mathrm{aA}$ & $203,125 \mathrm{aA}$ & $193,125 \mathrm{aA}$ \\
\hline BRS-Cauamé & $49.8 \mathrm{aC}$ & $71.7 \mathrm{aA}$ & $65.5 \mathrm{aB}$ & $158,750 \mathrm{aB}$ & $237,500 \mathrm{aA}$ & $192,500 \mathrm{aB}$ \\
\hline
\end{tabular}

Means followed by the same lowercase letter in the column and uppercase letter on the row, do not differ by the Tukey test at 5\% probability. S1 = December 14, 2012; S2 = January 14, 2013; S3 = February 14, 2013.

The cultivars BRS-Itaim and BRS-Novaera had the lowest final plant populations in the December sowing, however, in the other sowing seasons, they did not had populations lower than the other cultivars (Table 4). The cultivar BRS-Itaim and $B R S$-Novaera have high susceptibility to the fungus
Sclerotium rolfsii, which causes the Sclerotium wilt. This was the main factor for the low plant population of these cultivars in $\mathrm{S} 1$.

Regarding the shoot dry weight and number of grains per pod, significant effects was found for these factors only when evaluated singly (Table 5).

Table 5. Analysis of variance of the shoot dry weight and number of grains per pod of six cowpea cultivars depending on different sowing seasons, in the Cerrado biome. Uberaba, Minas Gerais, Brazil, 2012/13.

\begin{tabular}{|c|c|c|}
\hline Variation sources & $\begin{array}{l}\text { Shoot dry weight } \\
\left.\qquad \text { (g plant }^{-1}\right)\end{array}$ & $\begin{array}{c}\text { Grains per pod } \\
\text { (number) }\end{array}$ \\
\hline \multicolumn{3}{|l|}{ Cultivars (C) } \\
\hline BRS-Itaim & $25.8 \mathrm{a}$ & $5.6 \mathrm{c}$ \\
\hline BRS-Guariba & $18.7 \mathrm{~b}$ & $8.4 \mathrm{a}$ \\
\hline BRS-Tumucumaque & $18.9 \mathrm{~b}$ & $6.5 \mathrm{~b}$ \\
\hline BRS-Novaera & $23.4 \mathrm{a}$ & $5.7 \mathrm{c}$ \\
\hline BRS-Potengi & $21.1 \mathrm{~b}$ & $6.8 \mathrm{~b}$ \\
\hline BRS-Cauamé & $21.6 \mathrm{~b}$ & $6.7 \mathrm{~b}$ \\
\hline \multicolumn{3}{|l|}{ Sowing seasons (S) } \\
\hline $\mathrm{S} 1$ & $33.1 \mathrm{a}$ & $5.1 \mathrm{c}$ \\
\hline S2 & $14.1 \mathrm{c}$ & $6.2 \mathrm{~b}$ \\
\hline $\mathrm{S} 3$ & $17.5 \mathrm{~b}$ & $8.5 \mathrm{a}$ \\
\hline Variation sources & \multicolumn{2}{|c|}{ Mean square } \\
\hline Cultivars (C) & $88.83^{*}$ & $12.89 * *$ \\
\hline Sowing seasons (S) & $2,476.59 * *$ & $72.71 * *$ \\
\hline $\mathrm{C} \times \mathrm{S}$ interaction & $59.07^{\mathrm{ns}}$ & $2.14^{\mathrm{ns}}$ \\
\hline CV (\%) & 26.1 & 18.1 \\
\hline General average & 21.5 & 6.6 \\
\hline
\end{tabular}

Means followed by the same lowercase letter in the column do not differ by the Tukey test at $5 \%$ probability. $*=$ significant at $5 \%$ of probability by the $\mathrm{F}$ test; $* *=$ significant at $1 \%$ of probability by $\mathrm{F}$ test; ns $=$ not significant by F test. S1 = December 14, 2012; S2 = January 14, 2013; S3 = February 14, 2013. 
The cultivars BRS-Itaim and BRS-Novaera had greater accumulation of shoot dry matter (Table 5) compared with the other cultivars. The conditions in $\mathrm{S} 1$ contributed to this result, since it had the greater precipitation and higher temperatures compared with the other sowing seasons (Figure 1A, $1 \mathrm{~B}$ and 1C). Didonet and Vitória (2006) reported that vegetative characteristics of common bean under high temperatures vary with the cultivar, plant phenological phase, region and even with the sowing season in a same location. The increase in leaf area and dry weight and the decrease in number of pods per area and grain dry weight are some of the results that indicate these variations. Those conditions can cause significant decrease in grain yield due to a great plant vegetative growth at the expense of grain production. Moreover, cowpea plants of indeterminate growth habit present overlapping of vegetative and reproductive phases, which affects the source-drain relation, resulting in changes in the photoassimilates distribution in adult plants, altering their morphology, production components and grain yield (BEZERRA et al., 2009; BLOOM, 2013).
The cultivar BRS-Guariba had higher number of grains per pod compared with the other cultivars (Table 5). The S3 had higher average values of grains per pod compared with the S1 and S2. These results confirm those found by Silva (2011) in Vitória da Conquista, Bahia. However, Vieira (2001) found higher averages of grains per pod in an experiment conducted in Leopoldina, Minas Gerais. According to Summerfield, Pate and Roberts (1985), in addition to the genetic characteristic, other factors such as excessive humidity, high temperatures and little light (due to high plant densities), as well as biotic factors such as attacks of insect pests and diseases, may affect the number of grains per pod.

The 100-grain weight ranged from $24.3 \mathrm{~g}$ (BRS-Novaera) to $16.0 \mathrm{~g}$ (BRS-Cauamé) in $\mathrm{S} 1$ (Table 6). Matoso et al. (2013) reported similar results for BRS-Novaera, in Botucatu, São Paulo. The cultivar BRS-Itaim had significant values of 100-grain weight in S1 and S3. The BRS-Tumucumaque, BRS-Itaim and BRS-Potengi had higher values of 100-grain weight in S2.

Table 6. Unfolding of interaction between cultivars and sowing seasons for the 100 -grain weight and grain yield of six cowpea cultivars depending on different sowing seasons, in the Cerrado biome. Uberaba, Minas Gerais, Brazil, 2012/13.

\begin{tabular}{lccrrrr}
\hline & \multicolumn{3}{c}{$\begin{array}{c}\text { 100-grain weight } \\
\text { Cultivars }\end{array}$} & $\mathrm{S} 1$ & \multicolumn{1}{c}{$\mathrm{S} 2$} & \multicolumn{2}{c}{ Sowing seasons } & \multicolumn{2}{c}{$\begin{array}{c}\text { Grain yield } \\
\left(\mathrm{kg} \mathrm{ha}^{-1}\right)\end{array}$} \\
\cline { 2 - 7 } & $24.1 \mathrm{aA}$ & $19.8 \mathrm{abB}$ & $22.4 \mathrm{aA}$ & $873 \mathrm{cC}$ & $1,710 \mathrm{cB}$ & $3,439 \mathrm{aA}$ \\
\hline BRS-Itaim & $18.2 \mathrm{bcA}$ & $17.7 \mathrm{bcA}$ & $18.1 \mathrm{bcA}$ & $1,373 \mathrm{aC}$ & $1,746 \mathrm{cB}$ & $3,168 \mathrm{abA}$ \\
BRS-Guariba & $18.8 \mathrm{bA}$ & $20.6 \mathrm{aA}$ & $20.2 \mathrm{abA}$ & $1,530 \mathrm{aB}$ & $2,859 \mathrm{aA}$ & $3,071 \mathrm{bA}$ \\
BRS-Tumucumaque & $24.3 \mathrm{aA}$ & $17.8 \mathrm{bcC}$ & $20.5 \mathrm{abB}$ & $978 \mathrm{bcB}$ & $994 \mathrm{~dB}$ & $3,435 \mathrm{aA}$ \\
BRS-Novaera & $17.9 \mathrm{bcA}$ & $18.9 \mathrm{abcA}$ & $18.9 \mathrm{bcA}$ & $1,260 \mathrm{abC}$ & $2,489 \mathrm{bB}$ & $3,107 \mathrm{abA}$ \\
BRS-Potengi & $16.0 \mathrm{cA}$ & $16.4 \mathrm{cA}$ & $17.5 \mathrm{cA}$ & $1,245 \mathrm{abC}$ & $1,702 \mathrm{cB}$ & $2,915 \mathrm{bA}$ \\
BRS-Cauamé & &
\end{tabular}

Means followed by the same lowercase letter in the column and uppercase letter on the row, do not differ by the Tukey test at 5\% probability. S1 = December 14, 2012; S2 = January 14, 2013; S3 = February 14, 2013.

The average values of grain yield in the experiment (Table 6) were higher than the values found by Freire Filho et al. (2011) in the Brazilian Northeast $\left(330 \mathrm{~kg} \mathrm{ha}^{-1}\right)$, North $\left(831 \mathrm{~kg} \mathrm{ha}^{-1}\right)$ and Midwest $\left(960 \mathrm{~kg} \mathrm{ha}^{-1}\right)$ regions. The cultivars BRS-Itaim and BRS-Novaera had lower grain yields than the other cultivars in S1. However, these cultivars had higher grain yields than the others in S3 (as well as BRS-Guariba and BRS-Potengi), denoting the importance of studies comparing the agronomic performance of cultivars in different sowing seasons in the same region.

The cultivars BRS-Itaim and BRS-Novaera had the lowest grain yields in S1, probably due to the greater susceptibility of these cultivars to Sclerotium wilt and, consequently, due to the lower final plant population, according to the results shown in Table 4.

The cultivar BRS-Tumucumaque had the greatest grain yield average $\left(2,859 \mathrm{~kg} \mathrm{ha}^{-1}\right)$ in $\mathrm{S} 2$, compared with to the other cultivars, standing out also in S1, but not differing from the BRS-Guariba, BRS-Potengi and BRS-Cauamé (Table 6). All cultivars had high productive performance in S3, ranging from $2,915 \mathrm{~kg} \mathrm{ha}^{-1}$ (BRS-Cauamé) to $3,439 \mathrm{~kg} \mathrm{ha}{ }^{-1}$ (BRS-Itaim). The decrease in precipitation in the final phase of experiment in S3 did not affect the grain yield because the plants had no water stress up to the flowering stage (Figures $1 \mathrm{~A}, 1 \mathrm{~B}$ and $1 \mathrm{C}$ ), confirming the results found by Matoso et al. (2013) in Dourados, Mato Grosso do Sul, during the winter crop of 2009.

The S3 sowing season provided grain yields values higher than those reported by Teixeira et al. (2010), Matoso et al. (2013) and Matoso (2014) under rainfed conditions, and by Silva and Neves (2011) and Silva et al. (2013) with the use of irrigation. These results show that the cowpea has significant productive potential (HALL et al., 2003; ALVES et al., 2009) and cowpea cultivars of 
semi-erect growth habit evaluated in this study showed adaptation to the edaphoclimatic conditions of the Cerrado biome, in Uberaba, Minas Gerais.

\section{CONCLUSIONS}

The agronomic performance of cowpea cultivars was affected by the environmental conditions of the sowing seasons evaluated (December 2012, January and February 2013) in the Cerrado biome, in Uberaba, Minas Gerais (MG), Brazil.

The cowpea cultivars sown in December had lower numbers of pods per plant and grains per pod, resulting in lower grain yields, compared with the other sowing seasons (January and February), in the Cerrado biome, in Uberaba MG.

The cowpea cultivars sown in February had higher grain yields compared with the other sowing seasons, in the Cerrado biome of Uberaba, Minas Gerais, especially the cultivars BRS-Itaim, BRS-Novaera, BRS-Guariba and BRS-Potengi.

\section{ACKNOWLEDGEMENTS}

The authors thank the Embrapa Mid-North for providing the seeds of the cowpea cultivars.

\section{REFERENCES}

ALVES, J. M. A. et al. Avaliação agroeconômica da produção de cultivares de feijão-caupi em consórcio com cultivares de mandioca em Roraima. Revista Agro@mbiente On-line, Boa Vista, v. 3, n. 1, p. 15-30, 2009.

BARROS, M. A. et al. Adaptabilidade e estabilidade produtiva de feijão-caupi de porte semiprostrado. Pesquisa Agropecuária Brasileira, Brasília, v. 48, n. 4, p. 403-410, 2013.

BEZERRA, A. A. C. et al. Características de dossel e de rendimento em feijão-caupi ereto em diferentes densidades populacionais. Pesquisa Agropecuária Brasileira, Brasília, v. 44, n. 10, p. 1239-1245, 2009.

BLOOM, A. J.; BRISKIN, D. P Assimilação de nutrientes minerais. In: TAIZ, L.; ZEIGER, E. (Eds.). Fisiologia Vegetal. 5. ed. Porto Alegre: Artmed, 2013. cap. 12, p. 343-368.

CAMPOS, J. H. B. da C.; SILVA, M. T.; SILVA, V. de P. R. Impacto do aquecimento global no cultivo do feijao-caupi, no Estado da Paraíba. Revista Brasileira de Engenharia Agrícola e Ambiental,
Campina Grande, v. 14, n. 4, p. 396-404, 2010.

CARDOSO, M. J.; MELO, F. B. de.; LIMA, M. G. de. Ecofisiologia e manejo de plantio. In: FREIRE FILHO, F. R.; LIMA, J. A. de A.; RIBEIRO, V. Q. (Eds.). Feijão-caupi: avanços tecnológicos. Brasília: Embrapa Informação Tecnológica, 2005. p. 213-225.

DIDONET, A. D.; VITÓRIA, T. B. Resposta do feijoeiro comum ao estresse térmico aplicado em diferentes estágios fenológicos. Pesquisa Agropecuária Tropical, Goiânia, v. 36, n. 3, p. 199204, 2006

EZEAKU, I. E.; MBAH, B. N.; BAIYERI, K. P. Planting date and cultivar effects on growth and yield performance of cowpea (Vignaunguiculata (L.) Walp). African Journal of Plant Science, Lagos, v. 9, n. 11, p. 439-448, 2015

FREIRE FILHO, F. R. et al. Feijão-caupi no Brasil: Produção, melhoramento genético, avanços e desafios. 1. ed. Teresina, PI: Embrapa, 2011. 84 p.

FREITAS, R. M. O. et al. Produção de feijão-caupi sob efeito de veranico nos sistemas de plantio direto e convencional. Semina: Ciências Agrárias, Londrina, v. 34, n. 6, p. 3683-3690, 2013.

HALL, A. E. et al. Development of cowpea cultivars and germplasm by the Bean/Cowpea CRSP. Field Crops Research, Amsterdam, v. 82, n. 2-3, p. $103-$ 134, 2003.

MATOSO, A. O. Épocas de semeadura e populações de plantas para cultivares de feijãocaupi no outono-inverno em Botucatu-SP. 2014. 134 f. Tese (Doutorado em Agronomia: Área de Concentração em Agricultura) - Universidade Estadual Paulista, Faculdade de Ciências Agronômicas, Botucatu, 2014.

MATOSO, A. O. et al. Desempenho agronômico de feijão-caupi e milho semeados em faixas na safrinha. Pesquisa Agropecuária Brasileira, Brasília, v. 48, n. 7, p. 722-730, 2013.

MELO, F. de B.; CARDOSO, M. J.; SALVIANO, A. A. C. Fertilidade do solo e adubação. In: FREIRE FILHO, F. R.; LIMA, J. A. de A.; RIBEIRO, V. Q. (Eds.). Feijão-caupi: avanços tecnológicos. Brasília: Embrapa Informação Tecnológica, 2005. p. 231-241.

MORTIMORE, M. J. et al. Cowpea in traditional cropping systems. In: SINGH, B.B. ET AL. (Eds.). Advances in cowpea research. 1. ed. IITA, Ibadan, Nigeria: Copublication of International Institute of Tropical Agricutluture (IITA) and Japan International Research Center for Agricultural Sciences (JIRCAS), 1997. cap. 9, p. 99-113. 
OCHIENG, J.; KIRIMI, L.; MATHENGE, M. Effects of climate variability and change on agricultural production: The case of small scale farmers in Kenya. NJAS - Wageningen Journal of Life Sciences, Amsterdam, v. 77, s/n., p. 71-78, 2016.

OLIVEIRA, O. M. S. de.et al. Associações genotípicas entre componentes de produção e caracteres agronômicos em feijão-caupi. Revista Ciência Agronômica, Fortaleza, v. 44, n. 4, p. 851$857,2013$.

ROCHA, M. de M. et al. Controle genético do comprimento do pedúnculo em feijão-caupi. Pesquisa Agropecuária Brasileira, Brasília, v. 44, n. 3, p. $270-275,2009$.

SANTOS, J. F, dos et al. Produção e componentes produtivos de variedades de feijão-caupi na microrregião Cariri Paraibano. Engenharia Ambiental, Espírito Santo do Pinhal, v. 6, n. 1, p. 214-222, 2009.

SILVA, A. C. Características agronômicas e qualidade de sementes de feijão-caupi em Vitória da Conquista, Bahia. 2011. 84 f. Dissertação (Mestrado em Agronomia: Área de Concentração em Fitotecnia) - Universidade Estadual do Sudoeste da Bahia, Vitória da Conquista, 2011.

SILVA, E. F. da. et al. Avaliação de cultivares de feijão-caupi irrigado para produção de grãos verdes em Serra Talhada. Revista Caatinga, Mossoró, v. 26, n. 1, p. 21-26, 2013.

SILVA, J. A. L. da.; NEVES, J.A. Produção de feijão-caupisemi-prostrado em cultivos de sequeiro e irrigado. Revista Brasileira de Ciências Agrárias, Recife, v. 6, n. 1, p. 29-36, 2011.

SUMMERFIELD, R. J.; PATE, J. S.; ROBERTS, E. H. The physiology of cowpea. In: SINGH, S. R.; RACHIE. K. O. (Eds.). Cowpea research, production and utilization. Great Britain: WileyInterscience Publication, 1985. p. 65-102.

TEIXEIRA, I. R. et al. Desempenho agronômico e qualidade de sementes e cultivares de feijão-caupina região do cerrado. Revista Ciência Agronômica, Fortaleza, v. 41, n. 2, p. 300-307, 2010.

VIEIRA, R. F. Comportamento de cultivares de caupi do tipo fradinho em Leopoldina-MG. Revista Ceres, Viçosa, v. 11, n. 280, p. 730-733, 2001. 